\title{
TEACHER'S PERSPECTIVE AND PROBLEM TOWARD THE SYLLABUS CONTENT IN CURRICULUM 2013
}

\author{
SilviFitriani $^{1}$, RianSopian $^{2}$, Lilis Suryani $^{3}$ \\ ${ }^{1}$ IKIP Siliwangi \\ ${ }^{2}$ IKIP Siliwangi \\ ${ }^{3}$ IKIP Siliwangi \\ ${ }^{1}$ silvifitriani00@gmail.com, ${ }^{2}$ ryansofyan.garden@ gmail.com, ${ }^{3}$ suryani.lies@gmail.com
}

\begin{abstract}
The curriculum in Indonesia has been adjusted overtime. It is based on the world trends demanding the curriculum be sensible for those. One of the curriculum component, the syllabus, also changes its component and content in order to support the curriculum. There are some issues in the implementation of curriculum regarding to syllabus such as different content of the syllabus, new aims of syllabus development, and the time allocation. This study is conducted in order to investigate the real teacher's perspectives and problems toward the implementation of syllabus in Curriculum 2013. Qualitative descriptive method was used to obtain certain information. The data are gained through interview activities in order to analyze teacher's perspective and problem occurred in syllabus. The result show that teachers have ability to recognize the syllabus required and analyze the needs for the content of syllabus. However, the setting of time allocation which is only two hours in a week did not synchroniye with the syllabus content and government preparation. All in all, this study would be eligible to provide some perspectives in syllabus content development.
\end{abstract}

Keywords: Curriculum 2013, Syllabus Content, And Teacher's Perspective

\section{INTRODUCTION}

Curriculum is the main part of education system .According to Nunan, is (1998) in Wahyuni (2016), Curriculum is a set of principles and procedures for the planning, implementation, evaluation, and management of an educational program. And also Curriculum in Indonesia has been set in Undang-Undang Nomor 20 Tahun 2003 tentang Sistem Pendidikan Nasional stated in (Peraturan Menteri Pendidikan dan Kebudayaan Nomor 69 tahun 2013, 2013) : Bahwa kurikulum adalah seperangkat rencana dan pengaturan mengenai tujuan, isi, dan bahan pelajaran serta cara yang digunakan sebagai pedoman penyelenggaraan kegiatan pembelajaran untuk mencapai tujuan pendidikan tertentu.

Curriculum is like a soul in education. It is designed to support the implementation at schools and for teachers that can support to help the students to understand, enjoy and take part in a wide creative education. Curriculum is changed overtime in order to adjust the trend needs. A number of efforts have been made to develop appropriate curricula in Indonesia. It focuses on developing content related to current student interests (Widyastono, 2014, p. 54). Yani (2014, p. 11) has been recorded that the government has changed the curriculum eleven times, in 1947, 1964, 1968, 1973,1975, 1984, 1994, 1999, 2004, 2006, and 2013 (Gani \& Mahjati, 2017).

The change in curriculum will lead to the change in Syllabus. The curriculum change would contribute to the difficulty on implementing syllabus in the classroom. According to Apsari (2018), the Curriculum demands teacher and school to be skilled and trained. Thus, in implementing the Curriculum teachers deal with some problems. It is in line with (Nurichsania, 
Nina Amalia \& Rachmajanti, 2010) who has investigated the use of an English syllabus in SMAN 3 Malang by using KTSP Curriculum. The result showed that English teacher did not implement an English syllabus in accordance with SBI regulation by the Ministry of Education and Culture. Furthemore, the teacher's syllabus was not fulfilled some criterias required on KTSP.

The result was in line with the study from (Istiqomah, 2012) who has conducted a research of English syllabus development at SMK Negeri 8 Malang. She found also that syllabus developing procedures did not completely follow the criteria of KTSP. It also did not take significance roles in determining the learning outcomes of the students.

Based on those problem and preceeding studies, this study is aimed to investigate the real teacher's perspectives and problem toward the implementation of syllabus in Curriculum 2013.

\section{METHOD}

This study conducts descriptive qualitative design. It is implemented to obtain some evidences regarding teacher's perspective on syllabus content in curriculum 2013 (Creswell, 2008). According Burns (1999: 17) taken from (Untari, 2017) interviews and discussion are face-to face personal interaction, which generate data about the research issue and allow specific to discuss from other people perspective. Interview is used to gain a lot of information regarding to the implementation of Syllabus in Curriculum 2013.

The subjects in this research are five English education teachers in Senior High School level who are conducting the content syllabus in curriculum 2013. This purposive sampling is used based on the rationale that they are English teachers who teach and use the syllabus as one of a tool of teaching in the classroom. Besides, they have got experienced in educational system, development and setting in Indonesia.

The research instrument employed is an interview to obtain the respondents' viewpoint and reaction toward the syllabus content in Curriculum 2013. The rationale of taking this interview is to get enough information regarding the proposed research questions addressing respondents' perception and also comments on syllabus content in Curriculum 2013 in EFL context.

The instrument that this study conduct to support and answer the research question is using interview to the teachers. Alwasilah (2002) states that by interviewing the respondent, a researcher can get in-depth information because of some reasons, such as the researcher can explain and paraphrase the questions which cannot be understood by respondents, the researcher can give follow up questions, respondents tend to answer the question when they are asked, and respondents can tell something in the past and the future.

The steps to conduct this research are as follows.

a. The research subject is determined by using purposive sampling.

b. The interview method is formulated by combining certain points of the interview result in order to obtain enough information.

c. Recorder application from the mobile phone is conducted as the supported media of the interview.

d. General information and the respondent identities were displayed into R1, R2, R3 and so on are done to keep the secrecy.

e. The data will be collected and analyzed to accomodate the findings. 


\section{RESULTS AND DISCUSSION}

\section{Results}

\section{A. Teacher's viewpoint toward the syllabus content in Curriculum 2013}

Every teacher has a different general ideas in viewing the syllabus content in Curriculum 2013. The participants involved in this study have taken not only the syllabus content in Curriculum 2013, but also the previous curriculum that may be some additional information on this finding. The results are as follow.

\section{Section 1:}

R1: The content of subject matter in syllabus is being reduced in the implementation of Curriculum 2013. For example, usually we teach for about four or five genres in one semester, but now it is only two genres.

R2: Ok, in my opinion, kurtilas, we can say that, kurtilas, is very complicated syllabus I think. Because there are so many texts that we should take point for the assessment itself R3: In my opinion, there isn't any difference with the previous one. GBA still dominate the approach in the syllabus content in K-13.

R4: I think, it is more complex. The text types are divided nicely in each semester, so that in material design, it is not a problem to be picked and put through the lesson plan.

R5: Content of syllabus in Curriculum 2013 include the scope of the material or study yah..then, the purposes of the syllabus itself, because as I know different syllabus in one curriculum, the purposes are also different. There are also kompetensi inti and kompetensi dasar. I think that's I know about syllabus content in Curriculum 2013.

Apparently, there were two viewpoint regarding to the results showed above. The first perspectives is this curriculum are different with the previous one. The differenceies of curriculum are stated by first and fifth respondent. The differences lie in the content of subject matters which is more reduced and also the purpose. The second perspective is complicated. It can be seen from the type of assesment as stated by the second respondent, more methods applied as stated by the third respondent 
Section 2:

R1: In 2016, there are some revisions in the content. The government try to synergize between the basic competences, the materials in syllabus and in the book, so, it is better than before. In 2016 revision, the government only gives the basic competences and the rest, the teachers are asked to design on the syllabus.

R2: They can do observing and asking, and possessing and surfing, and concluding. Of course in the last day they can creating. So, the student itself has been stimulated by the syllabus.

R3: The content of syllabus in $K-13$ I think it is more flexible and easier to develop by the teachers.

R4: And then, now in 2016 revision, government seems like to challenge the teachers to design the syllabus themselves, I mean not all contents yah, but in some parts, ya, as teachers we try to create syllabus. The brightside is that, we feel free to construct the from the curriculum and syllabus guidance that were given by the government.

From the section 2 above, the viewpoint tends to move into more practical in syllabus content in Curriculum 2013. The first and the fifth respondent said that in 2016 curriculum revision, government tried to give opportunity for the teachers to design some parts of the syllabus, meanwhile the government only create the basic competences of the syllabus. This point of view showed that government was trying to find the solution and solve the problems in syllabus content that appeared in the beginning of Curriculum 2013. Thus, there was a good initiative by the government to put interest in fixing the curriculum and its syllabus.

Furthermore, the second respondent was commented on the syllabus implementation to the students in the classroom. R2 has mentioned the steps of scientific approach which is the main approach in all subjects in Curriculum 2013. Moreover, R2 stated that syllabus content in Curriculum 2013 accommodate students to be more active and critical to create some products or works that would be useful for the students themselves. Furthermore, the third respondent thought that the syllabus content was flexible and easier to be developed by the teacher because the content was clear.

\section{B. Teacher's problem in syllabus content in Curriculum 2013}

This study believes that the curriculum development from KTSP (School-Based Curriculum) into Curriculum 2013 has emerged not only positive effects, but also negative effects for both teachers and students. This finding is intended to seek the problems occurred in syllabus content in Curriculum 2013. 


\section{Section 3:}

R1: However, the funny thing happens when the content of the syllabus are different with the books, so the teachers were so confused which one should be followed. Then, the instructions say that just follow the book, then the teacher follow the books. At the first time it is launched, there was only student's book and syllabus. No teacher's book which gives more guidelines. So, we were confused at the beginning about this new term and how to implement that, although, we have googling that on the internet. It is something new for us that there was no socialization how to conduct it. There was no enough socialization about the syllabus on focus on how to transfer it to lesson plan, but not the real content because the instructor usually are from supervisors, headmasters, or national instructor from other lesson who gives the sample from the other subject matters.

R2: Because it spends much time. Sometimes, time allocation is not enough

R3: The transition would be the most difficult one to be applied. Even though, there is no significant difference between syllabus content in Curriculum 2013 and the previous one, but still it needs time and hard work by the teachers to study and learn the new syllabus. Oh..iya, sometimes, the time is not enough to be implemented from the syllabus in the classroom.

R4: Government socialization, for me should be more implemented by doing seminars, workshops, kunjungan or schools visit can be a solving problem for some teachers who still hard to understand the syllabus content.

The section 3 has given big layout about the problem in syllabus content in Curriculum 2013 at its first launching. There were so many inadequate information about the new syllabus and imperfect preparation, so that teachers confused to use the syllabus content. The first respondent has shared clear information about the syllabus content in Curriculum 2013, when the first launching. There were so chaotic situation that there wasn't strong information regarding the different content between the syllabus and the books. Besides, less control and supervised by the expert instructors has made the syllabus content was difficult to be understood by the teachers. Therefore, the second respondent said that sometimes, the time allocation is not adequate to be fulfilled. In line with the first respondent, perhaps the government still managing the appropriate setting for the best syllabus which will be implemented into lesson plan. So that, the time management somehow, was not suitable with the fact in the reality at schools. Meanwhile, the third and fourth more and less were leading with government socialization problems when teachers stuck with the syllabus content and the smooth transition from the previous syllabus. 
Section 4:

R1: Many interpretations of transferring the syllabus into the lesson plan, so the teachers were busied in some pedagogical stuff administration.

R2: And of course if we do not prepare it first, it will be hard to control the class itself because the teacher itself should understand and comprehend first. And sometimes, the teacher too busy and they want to learn about kurtilas or aspects contain in that syllabus. So, we are...sometimes, we are less preparation, so, the teaching learning is not really perfect.

R3: The problem, may be it is hard to maintain or what we call it...to be consistent to stick with the syllabus content in Curriculum 2013. Sometimes, we should take a look the syllabus content again and again to avoid some mistakes in applying syllabus content.

Other problems appeared in section 4, indicated to the teachers' side. Both first and second respondent have stated almost the same problem. Teachers were too busy with learning and adapting syllabus content in Curriculum 2013. They have been busied with administration stuff such as learning syllabus content and its purposes, so that, sometimes, they have forgotten to prepare their teaching materials in the classroom. Then, the fifth respondent realized that it was difficult to stick with the content of syllabus in Curriculum 2013 because unconsciously, we were too busy with teaching activity without looking the syllabus content regularly.

\section{Discussion}

All in all, in general the study results show that there were two different viewpoint about syllabus content in Curriculum 2013. The first respondent presumed that in Curriculum 2013, the subject matter in the syllabus is reduced from four or five genres to only two genres in one semester. Furthermore, the difference were from the general content of the syllabus and text types (genre) or content material from the syllabus. Meanwhile, the second respondent said that it was difficult and complicated, because the assessment will take so many text types to be measured and assessed to the students. However, the appreciation responses showed to goverment for doing some revision to curriculum regarding to assesment. However, the problems relating to chaotic situation that there wasn't strong information regarding the different content between the syllabus and the books. Besides, less control and supervised by the expert instructors has made the syllabus content was difficult to be understood by the teachers. Thus, the syllabus arrangement doesn't fully fullfill the criteria in 2013 curriculum. It is in line with Istiqomah (2013) who has conducted a research of English syllabus development in KTSP Curriculum at SMK Negeri 8 Malang. The findings showed that the vision and missions of the school and curriculum use for English subject which combined with SMA and SMK curriculum have influenced in syllabus development in that school. The syllabus developing procedures did not completely follow the criteria of KTSP. It also did not take significance roles in determining the learning outcomes of the students.

Regarding to the challenges in Implementation, there are several factors impacting on the implementation of curriculum change. The most widely cited are the factors proposed by Fullan (2007). These factors are organized into three main categories: characteristics of change, local 
characteristics and external factors.Some strategies in implementing new curriculum proposed by Print. According to Print (1993) a new curriculum can be implemented more succesfully in a school when cognisance and action are taken of the following points:

1. A deliberate strategy is developed to implement the curriculum in the school.

2. The curriculum is presented in terms of its favourable characteristics.

3. Support is obtained at a systemic level for the innovation.

4. The characteristics of the school are disposed toward the innovation.

\section{CONCLUSION}

Reflecting from the findings that have been analyzed in the previous chapter, this study is intended to investigate teacher's viewpoint and to examine teacher's problems toward the syllabus content in Curriculum 2013. In general, syllabus content in Curriculum 2013 has promoted and contributed to the development of education in Indonesia. Syllabus also puts its role as important root to design better lesson plan to be implemented in the real situation in the classroom.

From government point of view, it is better to plan the strategies, procedures of implementing curriculum and other supporting components well. It will create another obstacles for the government themselves when the implementation of the curriculum 2013 and its components are not fit with the plan or the purposes that have been set. It will become useless and government should work twice harder to mend the problems. Moreover, the better supervising should be more comprehensive to be done in all schools which are using syllabus content in Curriculum 2013 in order to avoid misconception along the process of adapting and implementing the syllabus.

From the teachers' perspective, they have to prepare all possibilities regarding the curriculum development any time. It is strongly believed that the government has the logical reasoning to develop previous curriculum into the new one. Communication and discussion among other teachers are necessary to be done by the teachers to share ideas, to solve the problems, and to get information from the classroom experience to discuss the syllabus content in Curriculum 2013.

\section{ACKNOWLEDGMENTS}

I would like to express my sincere apprecation tio the teachers participants of this research. And we express too sincere gratitude to the family, parents, friend, my beloved, and lectures who have given us support, so that we can complete and publish our jurnal.

\section{REFERENCES}

Alwasilah, A. C. (2002). Pokoknya Kualitatif. Jakarta: Pt. Kiblatbuku.

Apsari, Y. (2018). Teachersâ€TM Problems And Solutions In Implementing Curriculum 2013. Acuity: Journal Of English Language Pedagogy, Literature And Culture, 3(1), 11-23.

Creswell, J. W. (2008). Educational Research: Planning, Conducting, And Evaluating Quantitative And Qualitative Research (3rd Ed) (3rd Ed). New Jersey: Pearson International Edition.

Fullan, M. (2007). The New Meaning Of Educational Change. (Teachers Collegepress, Ed.). New York: Columbia University.

Gani, S. A., \& Mahjati, R. (2017). English Teacher's Knowledge For Implenting The 2013 
Curriculum. English Education, 8(2), 199-212.

Istiqomah, H. (2012). The Development Of English Syllabus And Lesson Plans At Smk Negeri 8 Malang. E-Jurnal.

Nurichsania, Nina Amalia \& Rachmajanti, S. (2010). A Study On The Implementation Of An English Syllabus And. E-Jurnal. Retrieved From Http;/KaryaIlmiah.Um.Ac.Id/Index.Php/Sastra-Inggris/Article/View/20744

Peraturan Menteri Pendidikan Dan Kebudayaan Nomor 69 Tahun 2013. (2013). Kerangka Dasar Dan Struktur Kurikulum Sekolah Menengah Atas/Madrasah Aliyah. Jakarta: Menteri Pendidikan.

Print, M. (1993). Curriculum Development And Design (2nded). Malaysia: Srm Production Services Sdn Bhd.

Untari, S. D. (2017). The Implementation Of Scientific Approach In Teaching Reading Comprehension For The Tenth Grade Students Of Sman 2 Karanganyar In 2016/2017 Academic Year. The State Islamic Institute Of Surakarta.

Wahyuni, S. (2016). Curriculum Development In Indonesian Context. Universum, 10(1), 73 82. 